\title{
PENGARUH FIRM SIZE, FINANCIAL DISTRESS, DEBT LEVEL, DAN MANAGERIAL OWNERSHIP TERHADAP KEPUTUSAN HEDGING PADA PERUSAHAAN MANUFAKTUR YANG TERDAFTAR DI BURSA EFEK INDONESIA
}

\author{
Husna Anniyati ${ }^{1}$, Hermanto ${ }^{2}$, Siti Aisyah Hidayati ${ }^{3}$ \\ 1Program Studi Magister Manajemen Fakultas Ekonomi dan Bisnis Unram \\ E-mail: husnaanniyati.ha@gmail.com \\ 2,3Fakultas Ekonomi dan Bisnis, Universitas Mataram
}

\begin{tabular}{|c|c|}
\hline ARTICLE INFO & ABSTRACT \\
\hline 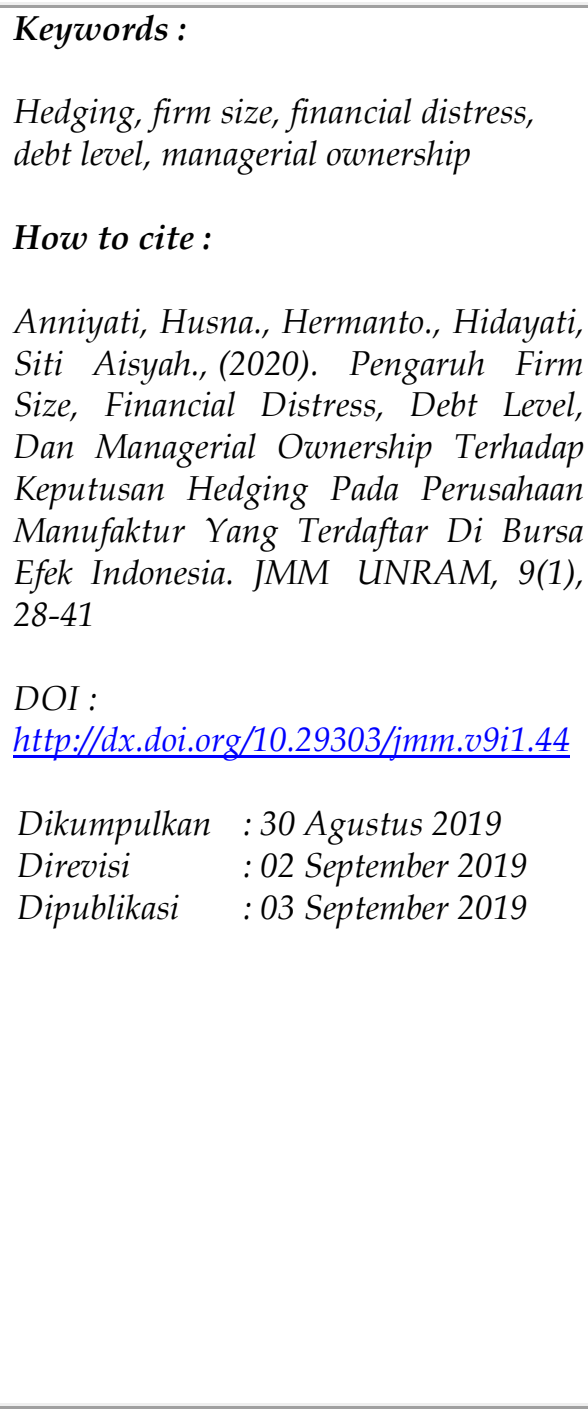 & $\begin{array}{l}\text { This study aims to analyze the influence of firm size, } \\
\text { financial distress, debt level, and managerial ownership on } \\
\text { hedging decisions on manufacturing companies listed on } \\
\text { the Indonesia Stock Exchange. This type of research is } \\
\text { associative-causality research. The population of this } \\
\text { research is all the go pubic manufacturing companies on } \\
\text { the Indonesia Stock Exchange, which are } 170 \text { companies. } \\
\text { The number of samples used was } 81 \text { companies, which } \\
\text { were taken using a purposive sampling method. Data } \\
\text { collection techniques use documentation techniques } \\
\text { obtained from the annual financial statements of } \\
\text { manufacturing companies. The data analysis technique } \\
\text { uses the logistic regression analysis method. The results of } \\
\text { data analysis show that: (1) firm size and managerial } \\
\text { ownership variables have a positive and significant effect } \\
\text { on hedging decisions and (2) financial distress and debt } \\
\text { levels have a negative and insignificant effect on hedging } \\
\text { decisions. } \\
\text { Penelitian ini bertujuan untuk menganalisis pengaruh } \\
\text { firm size, financial distress, debt level, dan managerial } \\
\text { ownership terhadap keputusan hedging pada perusahaan } \\
\text { manufaktur yang terdaftar di Bursa Efek Indonesia. } \\
\text { Jenis penelitian ini adalah penelitian asosiatif- } \\
\text { kausalitas. Populasi penelitian ini adalah seluruh } \\
\text { perusahaan manufaktur yang go pubic di Bursa Efek } \\
\text { Indonesia yaitu sebanyak } 170 \text { perusahaan. Jumlah } \\
\text { sampel yang digunakan adalah sebanyak } 81 \\
\text { perusahaan, yang diambil menggunakan metode } \\
\text { purposive sampling. Teknik pengumpulan data } \\
\text { menggunakan teknik dokumentasi yang diperoleh } \\
\text { dari laporan keuangan tahunan perusahaan } \\
\text { manufaktur. Teknik analisis data menggunakan } \\
\text { metode analisis regresi logistik. Hasil analisis data }\end{array}$ \\
\hline
\end{tabular}




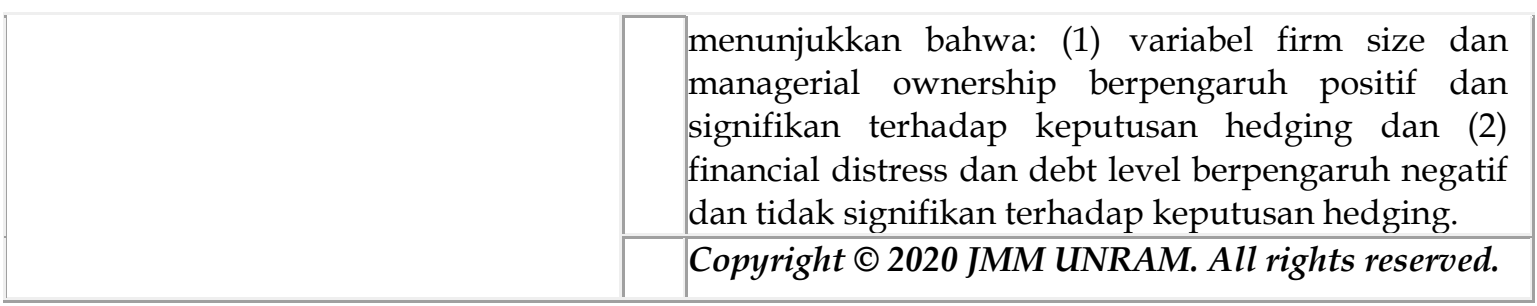

\section{PENDAHULUAN}

Perkembangan pada era globalisasi telah membuat interaksi antar negara semakin meningkat dalam bisnis internasional. Banyak perusahaan terlibat dalam bisnis internasional seperti perdagangan dan investasi internasional. Setiap negara berperan aktif dalam bisnis internasional ini. Globalisasi memberi peluang agar perusahaan dapat berkontribusi yaitu melakukan ekspor impor barang, ekspansi bisnis maupun pendanaan luar negeri.

Perdagangan internasional membuat pertukaran barang dan jasa yang menyebabkan pertukaran mata uang dengan mata uang lain dalam melakukan pembayaran transaksi bisnis. Nilai mata uang yang ditunjukkan dalam kurs dari waktu ke waktu mengalami fluktuasi sehingga terjadi perubahan arus kas yang dibutuhkan dan digunakan. Nilai mata uang setiap negara selalu berfluktuasi satu sama lainnya menyebabkan ketidakpastian bagi perusahaan yang terlibat dalam perdagangan internasional. Menurut Guniarti (2014) fluktuasi kurs valuta asing merupakan risiko terbesar dari transaksi multinasional. Fluktuasi tersebut berdampak langsung pada penjualan, penetapan produk, serta laba eksportir dan importir.

Dalam mengantisipasi ketidakpastiaan ini perusahaan dapat melakukan suatu kebijakan yang bisa meminimalisir dampak yang ditimbulkan yakni dengan mengambil keputusan hedging (lindung nilai). Hedging memberikan kepastian, pengendalian persediaan bahan baku dan komoditi, serta memberikan penyediaan dana yang lebih besar serta lebih aman.

Berdasarkan penelitian terdahulu bahwa penggunaan hedging di pengaruhi oleh beberapa faktor yang menunjukkan bahwa firm size, financial distress, debt level (Krisdian dan Badjra, 2017) dan managerial ownership (Mahfudz dan Kussulistyanti, 2016). Dalam penelitiannya menyatakan bahwa perusahaan besar dalam bisnisnya akan melakukan transaksi luar negeri sehingga akan menghadapi risiko yang lebih tinggi dan membutuhkan hedging karena perusahaan akan menghadapi eksposur valuta asing yang lebih besar. Perusahaan dengan ukuran yang besar akan menyadari pentingnya hedging untuk melindungi aset dan arus kas dan perusahaan mampu membeli derivatif valuta asing untuk kepentingan hedging.

Faktor - faktor yang mempengaruhi keputusan hedging yaitu berasal dari eksternal perusahaan dan juga internal perusahaan. Faktor eksternal yang mempengaruhi keputusan hedging antara lain BI rate, nilai tukar, dan inflasi yang menjadi acuan perusahaan dalam melakukan keputusan hedging (Sunaryo, 2009). Sedangkan faktor internal yang mempengaruhi dan mendorong perusahaan melakukan keputusan hedging diantaranya yaitu firm size, financial distress, debt level, dan managerial ownership.

Beberapa faktor internal yang mendorong suatu perusahaan melakukan keputusan hedging antara lain; Pertama Firm size merupakan ukuran besar kecilnya sebuah perusahaan yang ditunjukan atau dinilai oleh total asset, total penjualan, jumlah laba, beban pajak dan lain-lain (Brigham \& Houston 2010:4). Operasional yang mencakup antar negara akan menimbulkan eksposur valuta asing dan adanya risiko fluktuasi nilai tukar mata uang, 
sehingga perusahaan akan cenderung melakukan hedging untuk melindungi risiko tersebut. Hal ini sesuai dengan penelitian yang dilakukan oleh Clark dan Judge (2005) dan Paranita (2011) bahwa ukuran perusahaan memiliki pengaruh positif dan signifikan terhadap keputusan hedging perusahaan. Berbeda dengan hasil penelitian yang dilakukan oleh Krisdian dan Badjra (2017) mendapatkan hasil bahwa Firm Size berpengaruh negatif dan tidak signifikan terhadap keputusan hedging.

Faktor internal kedua yang mempengaruhi keputusan hedging suatu perusahaan adalah risiko kebangkrutan perusahaan (financial distress). Financial distress adalah suatu situasi dimana arus kas operasi perusahaan tidak memadai untuk melunasi kewajibankewajiban lancer seperti hutang dagang atau beban bunga (Indri, 2012:103). Perusahaan yang memiliki risiko yang tinggi akan melakukan aktivitas hedging untuk meminimalkan risiko tersebut. Hal ini sesuai dengan penelitian yang dilakukan oleh Krisdian \& Badjra (2010) menunjukkan bahwa financial distress memiliki pengaruh positif dan signifikan terhadap keputusan hedging. Namun, berbeda hasil penelitian dengan Guniarti (2014) menunjukkan hasil financial distress berpengaruh negatif terhadap keputusan hedging.

Faktor internal yang ketiga yaitu debt level. Hutang adalah semua kewajiban keuangan perusahaan kepada pihak lain yang belum terpenuhi, dimana hutang ini merupakan sumber dana atau modal perusahaan yang berasal dari kreditor (Munawir, 2004). Penggunaan hutang dapat membantu perusahaan dalam membiayai kegiatan produksi maupun ekspansi usaha, tapi di sisi lain penggunaan hutang luar negeri dalam jumlah besar akan sangat dipengaruhi oleh fluktuasi nilai tukar. Hal ini sesuai dengan penelitian yang dilakukan oleh Krisdian \& Badjra (2017) menunjukkan bahwa debt level berpengaruh positif dan signifikan terhadap keputusan hedging yang diproksikan melalui debt ratio. Hasil yang berbeda terjadi pada penelitian yang dilakukan oleh Thouraya (2006) menyatakan bahwa tingkat hutang berpengaruh negatif terhadap aktivitas hedging.

Faktor keempat yaitu managerial ownership, kepemilikan manajerial adalah pemegang saham dari pihak manajemen yang secara aktif dalam pengambilan keputusan perusahaan (Darwis, 2009). Manajer akan berusaha meminimalisir risiko yang terjadi agar tidak mengalami kerugian yang tidak diharapkan. Hal ini sesuai dengan penelitian yang dilakukan oleh Krisdian dan Badjra (2010) menunjukkan bahwa managerial ownership berpengaruh positif dan signifikan. Hasil yang berbeda terjadi pada penelitian (Prasetiono \& Hidayah, 2016) yang mendapatkan hasil bahwa managerial ownership berpengaruh negatif dan tidak signifikan terhadap keputusan hedging.

Badan Pusat Statistik (BPS) telah melaporkan perekonomian Indonesia tumbuh 6,17\% pada kuartal III-2017. Dengan pertumbuhan sebesar itu, selama periode Januari-September 2017 pertumbuhan ekonomi Indonesia mencapai 6,29\%. Rata-rata firm size pada perusahaan manufaktur yang terdaftar di Bursa Efek Indonesia periode 2016 - 2017 yaitu sebesar $28.793 \%$. Kondisi perekonomian yang kurang stabil seperti sekarang ini mempengaruhi keadaan perusahaan manufaktur yang terdaftar di bursa efek indonesia, dimana hal tersebut dapat menyebabkan probabilitas perusahaan mengalami kesulitan keuangan atau Financial Distress semakin tinggi. Melemahnya nilai tukar rupiah, maka jika suatu perusahaan mengimpor barang dari luar negeri, harga barang tersebut akan menjadi lebih mahal, sedangkan jika suatu perusahaan mengekspor barang hasil produksinya luar negeri, maka harga barang yang diekspor tersebut akan menjadi lebih murah. Manajemen perusahaan harus menganalisis, mempertimbangkan terlebih dahulu keputusan untuk menggunakan debt level ini sekaligus besarnya jumlah atas hutang yang masih mungkin ditanggung oleh perusahaan. Sedangkan perkembangan kepemilikan manajerial pada tahun 2014-2015 stabil sebesar 7,44\% dan mengalami penurunan pada tahun 2016 menjadi 7,02\% serta mengalami peningkatan pada tahun 2017 sebesar 0,04\% menjadi 7,06\%. 


\section{KAJIAN PUSTAKA}

\subsection{Landasan Teori}

\subsubsection{Hedging $(\mathrm{Y})$}

Hedging merupakan suatu tindakan untuk melindungi perusahaan terhadap risiko kerugian atas valuta asing dengan cara mengurangi atau menghindarinya sebagai akibat dari transaksi bisnis. Tindakan dan keputusan hedging biasanya dilakukan seputar dengan kondisi mengantisipasi timbulnya fluktuasi valuta asing (valas) di pasaran.

Dalam penelitian ini perusahaan yang melakukan keputusan hedging akan menggunakan dummy dalam pengukurannya.

\subsubsection{Firm Size (X1)}

Firm Size merupakan tolak ukur sebuah perusahaan telah berkembang atau tidak sejak perusahaan didirikan yang dapat dilihat dari nilai total asset yang tercantum di laporan posisi keuangan. Perusahaan besar akan bertindak hati-hati dalam pengelolaan perusahaannya dan lebih banyak melakukan hedging. Besar dan kecilnya perusahan dapat ditentukan berdasarkan total penjualan, total asset dan rata-rata tingkat penjualan. Semakin besar ukuran perusahaan, semakin besar risiko yang dihadapi oleh perusahaan tersebut (Seftianne, 2011). Menurut Harahap (2007:23) pengukuran ukuran perusahaan adalah "Ukuran perusahaan diukur dengan logaritma natural (Ln) dari rata-rata total asset perusahaan.

\subsubsection{Financial Distress $(X 2)$}

Financial Distress sebagai tahap penurunan kondisi keuangan yang terjadi karena kebangkrutan atau likuiditas. Financial Distress juga diartikan sebagai suatu kondisi yang dialami suatu perusahaan yang tidak dapat memenuhi kebutuhan perusahaan dan kewajiban-kewajibannya yang berada dalam kondisi tidak aman yang diprediksi akan mengalami kegagalan. Pengukuran financial distress dapat diproksikan dengan Interest Coverage Ratio (ICR) (Fahmi, 2014). Kondisi financial distress terlihat dari ketidakmampuan atau tidak tersedia dana pada perusahaan untuk membayar kewajiban pada saat jatuh tempo yang sudah ditentukan.

\subsubsection{Debt Level (X3)}

Hutang digunakan perusahaan untuk meningkatkan kinerja, seperti melakukan investasi atau untuk memenuhi kebutuhan modal kerja dikarenakan membutuhkan dana. Di sisi lain, hutang dapat meningkatkan kemungkinan risiko yang akan dihadapi oleh perusahaan (Subagya, 2015). Risiko tesebut dapat berupa jangka waktu hutang yang dapat mempengaruhi perusahaan, hutang yang terlalu tinggi dan ketidakmampuan membayar hutang. Variabel tingkat hutang dalam penelitian ini diukur menggunakan rasio hutang yaitu debt to equity ratio.

\subsubsection{Managerial Ownership (X4)}

Kekayaan manajer akan meningkat jika memiliki saham di perusahaannya apabila nilai perusahaan tersebut meningkat dalam kegiatan operasionalnya (Ameer, 2010). Manajer akan berusaha meminimalisir risiko yang terjadi agar tidak mengalami kerugian yang tidak diharapkan terutama dalam perdagangan internasional. Kepemilikan manajerial diukur dengan cara membandingkan saham yang dimiliki oleh manajer, perusahaan dengan jumlah keseluruhan saham yang beredar.

\subsubsection{Risiko dan Manajemen Risiko}

Risiko adalah kerugian akibat kejadian yang tidak dikehendaki. Risiko dapat diidentifikasi berdasarkan faktor penyebabnya, yaitu risiko karena pergerakan harga pasar dikategorikan sebagai risiko pasar. Risiko karena mitra transaksi gagal bayar dikategorikan 
sebagai risiko kredit. Sementara itu, risiko karena kesalahan atau kegagalan orang, sistem, proses dan faktor eksternal disebut risiko operasional (Sunaryo, 2009).

Manajemen risiko adalah pengidentifikasian peristiwa - peristiwa yang dapat memberikan konsekuensi keuangan yang merugikan dan kemudian mengambil tindakan untuk mencegah dan atau meminimalkan kerugian yang diakibatkan oleh peristiwaperistiwa tersebut (Brigham dan Houston, 2006).

\subsection{Penelitian Terdahulu}

Penelitian ini merujuk pada beberapa penelitian terdahulu sebagai acuan penulis melakukan penelitian terkait pengaruh firm size, financial distress, debt level, dan managerial ownership terhadap keputusan hedging pada perusahaan manufaktur, seperti penelitian yang dilakukan oleh Hafiz \& Maya (2015) bertujuan untuk mengetahui pengaruh leverage, financial distress, dan growth options terhadap aktivitas hedging. Hasil dari penelitian ini menunjukkan bahwa leverage berpengaruh positif terhadap aktivitas hedging, sedangkan financial distress dan growth options tidak berpengaruh terhadap aktivitas hedging.

Penelitian yang dilakukan oleh Sianturi (2015) tentang Pengaruh firm size, liquidity, leverage, growth opportunity financial distress, dan managerial ownerhip terhadap aktivitas hedging dengan instrument derivative (Studi Kasus Pada Perusahaan Yang Terdaftar Di BEI Periode 2010-2014). Hasil penelitian ini menunjukkan variabel firm size dan leverage, managerial ownerhip berpengaruh positif terhadap aktivitas hedging, dan variabel financial distress berpengaruh negatif terhadap aktivitas hedging.

\subsection{Hipotesis}

Berdasarkan teori dan latar belakang permasalahan yang telah dikemukakan sebelumnya maka dapat dibuat beberapa hipotesis terhadap permasalahan sebagai berikut

\subsubsection{Pengaruh Firm Size Terhadap Keputusan Hedging}

Firm size atau ukuran perusahaan adalah besar kecilnya perusahaan yang dapat dilihat dari besarnya nilai ekuitas, nilai penjualan, dan nilai total aktiva (Riyanto, 1999). Perusahaan yang besar cenderung mudah menjalankan aktivitasnya dalam memperoleh pendanaan dan cenderung memiliki kegiatan operasional yang lebih banyak sehingga cenderung akan menimbulkan risiko yang lebih besar pula sehingga mendorong suatu perusahaan besar untuk mengambil keputusan hedging agar terlindungi dari risiko. Beberapa penelitian mendukung penelitian ini yaitu penelitian yang telah dilakukan oleh Judge (2005), Raghavendra dan Velmurugan (2014) menemukan bahwa ukuran perusahaan memiliki hubungan yang positif dan signifikan terhadap keputusan hedging .

H1 : Firm size berpengaruh positif dan signifkan terhadap keputusan hedging.

\subsubsection{Pengaruh Financial Distress Terhadap Keputusan Hedging}

Financial distress atau kesulitan keuangan dapat diartikan sebagai ketidakmampuan perusahaan untuk membayar kewajiban keuangannya pada saat jatuh tempo yang menyebabkan kebangkrutan perusahaan (Darsono dan Ashari, 2005). Perusahaan yang mengalami kesulitan keuangan akan mendorong perusahaan untuk berhati-hati mengelola keuangannya sehingga terdorong untuk melakukan perlindungan dari berbagai risiko dalam melakukan transaksi valuta asing, maka dari itu perusahaan cenderung memutuskan melakukan hedging. Penelitian ini didukung oleh beberapa penelitian yaitu penelitian yang dilakukan oleh Krisdian \& Badjra (2010) yang mana hasil penelitian ini menyatakan financial distress berpengaruh positif signifikan terhadap keputusan hedging. $\mathrm{H} 2$ : Financial distress berpengaruh positif dan signifikan terhadap keputusan hedging. 


\subsubsection{Pengaruh Debt Level Terhadap Keputusan Hedging}

Perusahaan yang dalam struktur modalnya memiliki tingkat hutang yang tinggi cenderung akan lebih berhati-hati lagi dalam menjalankan operasi perusahaannya terutama dalam aktivitas transaksi luar negeri yang menggunakan valuta asing karena perusahaan tersebut selain harus membayar bunga yang tinggi akibat tingkat hutang yang tinggi, perusahaan juga tidak ingin manambah beban risiko akibat adanya fluktuasi kurs mata uang dalam melakukan transaksi luar negeri sehingga menyebabkan perusahaan akan mengelola risikonya dengan sangat ketat guna membatasi risiko dan mengurangi risiko fluktuasi kurs valuta asing yaitu dengan melakukan aktivitas hedging. Penelitian ini didukung oleh penelitian yang telah dilakukan Nguyen et al. (2003) menemukan pengaruh positif dan signifikan dari tingkat hutang terhadap penggunan derivatif dalam keputusan hedging.

H3 : Debt level berpengaruh positif dan signifikan terhadap keputusan hedging.

\subsubsection{Pengaruh Managerial Ownership Terhadap Keputusan Hedging}

Kepemilikan seorang manajer akan ikut menentukan kebijakan dan pengambilan keputusan. Manajer akan mengupayakan risiko yang terjadi seminim mungkin dikarenakan mempengaruhi laba atas investasi mereka di perusahaan. Hal ini membuat manajer untuk melakukan tindakan hedging dengan derivatif valuta asing guna mengurangi risiko nilai tukar perusahaan. Hal ini selaras dengan hasil penelitian yang telah dilakukan oleh Ameer (2010). Penelitian tersebut menunjukkan kepemilikan manajerial berpengaruh positif signifikan terhadap keputusan hedging.

H4 : Managerial ownership berpengaruh positif dan signifikan terhadap keputusan hedging.

\section{METODE PENELITIAN}

Jenis penelitian ini adalah penelitian asosiatif-kausalitas yaitu suatu penelitian yang meneliti pengaruh suatu variabel terhadap variabel lainnya atau mengetahui hubungan antar variabel (Sugiyono, 2014). Penelitian ini bertujuan untuk menganaisis adanya pengaruh dari variabel; $(X)$ yaitu pengaruh firm size, financial distress, debt level, dan managerial ownership terhadap (Y) keputusan hedging.

Populasi yang digunakan dalam penelitian ini adalah seluruh perusahaan manufaktur yang go pubic di Bursa Efek Indonesia yaitu sebanyak 170 perusahaan. Pengambilan sampel pada penelitian ini menggunakan metode purposive sampling.

Jenis data yang digunakan pada penelitian ini adalah data kuantitatif berupa angka dalam data tahunan laporan keuangan perusahaan. Berdasarkan sumber data yang digunakan dalam penelitian ini adalah data sekunder berupa data laporan keuangan tahunan yang diperoleh melalui situs website perusahaan manufaktur yang terdaftar di Bursa Efek Indonesia.

Teknik yang digunakan dalam penelitian ini adalah teknik dokumentasi yaitu teknik pengumpulan data yang diperoleh dari laporan tahunan, laporan keuangan perusahaan manufaktur yang terdaftar di Bursa Efek Indonesia dan dengan menggunakan teknik observasi tidak langsung yaitu teknik dokumentasi data sekunder.

Prosedur Analisis Data yaitu 1) Analisis deskriptif. 2) Analisis statistik deskriptif. 3) Analisis regresi logistik. Langkah-langkah melakukan analisis regresi logistik menurut Ghozali (2016:328) adalah :

1. Menilai Keseluruhan Model (Overall Model Fit)

Untuk menilai model fit ada beberapa tes statistik yang digunakan adalah sebagai berikut :

a. Nilai -2 Log Likehood (-2LogL) 
b. Omnibust Test of Model Coefficient

c. Koefisien Cox dan Snell's R square dan Nagelkerke's R square

d. Hosmer and Lemeshow's test.

2. Ketepatan Prediksi Model Regresi Logistik

3. Estimasi Parameter dan Uji Regresi Logistik

Estimasi maksimum likehood parameter dari model dapat dilihat pada tampilan output variable in the equation (Widarjono, 2010:148).

\section{HASIL PENELITIAN DAN PEMBAHASAN}

\subsection{Analisis Deskriptif Data}

Tabel 4.1

Rata-rata Firm Size, ICR, DER dan Kepemilikan Manajerial Perusahaan Manufaktur tahun 2016-2017

\begin{tabular}{|c|c|c|c|c|}
\hline \multirow{2}{*}{ Tahun } & \multicolumn{4}{|c|}{ Parameter } \\
\cline { 2 - 5 } & Size (Ln) & ICR & DER (\%) & KM \\
\hline 2016 & 28,75 & 83,50 & 113,10 & 6,74 \\
\hline 2017 & 28,84 & 42,81 & 121,39 & 7,91 \\
\hline
\end{tabular}

Sumber : Data Diolah, 2019

Tabel di atas menunjukkan bahwa size rata-rata perusahaan manufaktur yang diproksikan dengan Ln of Total Asset pada tahun 2016 adalah sebesar 28,75 meningkat menjadi 28,84 pada tahun 2017. Untuk variabel financial distress yang diproksikan dengan nilai ICR, dimana pada tahun 2016 ICR rata-rata adalah sebesar 83,50 yang kemudian mengalami penurunan menjadi 42,81 pada tahun 2017. Pada tahun 2016, variabel debt level yang diproksikan dengan rasio DER menunjukkan rata-rata sebesar 113,10\%. Tahun 2017 rata-rata DER mengalami peningkatan menjadi 121,39\%. Pada tahun 2016, variabel kepemilikan manajerial perusahaan manufaktur di BEI menunjukkan rata-rata sebesar 6,74\%. Sedangkan pada tahun 2017 rata-rata kepemilikan manajerial mengalami kenaikan menjadi 7,91. Penurunan nilai ICR menunjukkan adanya peningkatan kesehatan keuangan perusahaan serta perusahaan mengalamai kemudahan likuiditas yang ditunjukkan dengan kemampuan perusahaan yang semakin baik dalam memenuhi kewajibannya kepada kreditur.

\subsection{Analisis Statistik Deskriptif}

Berdasarkan data hasil olahan SPSS yang meliputi variabel independen, yaitu firm size yang merupakan proksi dari firm size (X1), financial distress yang diproksikan dengan ICR (X2), debt level yang diproksi dari DER (X3), dan rasio managerial ownership (X4) maka akan dapat diketahui nilai maksimum, nilai minimum, nilai rata-rata dan standar deviasi dari tiap-tiap variabel tersebut Tabel 1 menunjukkan statistik deskriptif variabel independen.

Tabel 4.2

Statistik Deskriptif Variabel Independen

\begin{tabular}{|l|c|c|c|c|c|}
\hline & N & Min & Max & Rata-rata & Standar Deviasi \\
\hline Size (Ln Total Asset) & 162 & 25,216 & 33,3 & 28,793 & 1,675 \\
\hline Financial Risk (ICR) & 162 & $-40,467$ & 4130,55 & 63,155 & 348,793 \\
\hline Debt Level (DER) & 162 & 0,000 & 890,800 & 117,244 & 126,949 \\
\hline $\begin{array}{l}\text { Kepemilikan Manajerial (KM) } \\
(\%)\end{array}$ & 162 & 0,000 & 95,38 & 7,327 & 16,765 \\
\hline
\end{tabular}

Sumber : Data Diolah, 2018 


\section{NATIONALLY ACCREDITED JOURNAL - DECREE NO. 21/E/KPT/2018}

Berdasarkan tabel di atas, rata-rata ukuran perusahaan (firm size) manufaktur di BEI adalah sebesar 28,793, dengan size minimum 25,216 dan maksimum 33,3. Untuk variabel financial risk (ICR) diperoleh rata-rata ICR sebesar 63,155, dengan ICR terendah -40,467 dan tertinggi 4130,55. Untuk variabel debt level yang diproksikan dengan nilai DER (Debt to Equity Ratio), rata DER perusahaan manufaktur adalah 117,244 dengan DER terrendah 0,000 dan tertinggi 890,800. Sedangkan untuk variabel kepemilikan manajerial (KM), diperoleh rata-rata sebesar 7,327\%, dengan rasio terrendah $0 \%$ dan tertinggi $95,38 \%$.

\subsection{Hasil Analisis Regresi Logistik}

\subsubsection{Hasil Pengujian Kelayakan Model}

Pengujian kelayakan model dilakukan untuk menilai kebaikan model regresi logistik yang dihasilkan. Uji ini meliputi uji goodness of fit test, overall fit test, dan koefisien determinasi.

\section{Goodness of Fit Test}

Pengujian kelayakan model (goodness of fit test) regresi logistik menggunakan uji Hosmer and Lemeshow Test. Uji ini bertujuan untuk menilai apakah probabilitas hasil prediksi sesuai dengan probabilitas hasil observasi. Hasil Hosmer dan Lameshow Test disajikan pada tabel berikut.

\section{Tabel 4.3}

Hasil Uji Hosmer and Lemeshow Hosmer and Lemeshow Test

\begin{tabular}{|c|r|r|r|}
\hline Step & $\begin{array}{c}\text { Chi- } \\
\text { square }\end{array}$ & Df & Sig. \\
\hline 1 & 8,646 & 8 &, 373 \\
\hline
\end{tabular}

Hasil uji Hosmer and Lemeshow menunjukkan nilai $\mathrm{X}^{2}$ hitung sebesar 8,646 dengan nilai probabilitas (sig.) sebesar 0,373 yang lebih besar daripada 0,05. Hal ini berarti bahwa hasil prediksi atau klasifikasi yang diprediksi sesuai dengan klasifikasi yang diamati. Itu berarti model regresi logistik dinilai tepat digunakan untuk menguji signifikansi pengaruh variabel independen terhadap variabel respon.

\section{Overall Fit Test}

Overall fit test digunakan untuk menguji pengaruh simultan variabel independen terhadap variabel respon berupa data kategorik. Uji ini menggunakan omnibus test dimana model dinyatakan layak atau variabel independen secara simultan berpengaruh signifikan terhadap variabel respon jika jika nilai probabilitas (sig.) Chi-square kurang dari 0,05.

Tabel 4.4

Hasil Uji Overall Fit Test

Omnibus Tests of Model Coefficients

\begin{tabular}{|ll|c|c|r|}
\hline & & Chi-square & Df & \multicolumn{1}{|c|}{ Sig. } \\
\hline \multirow{3}{*}{ Step 1 } & Step & 24,634 & 4 &, 000 \\
& Block & 24,634 & 4 &, 000 \\
& Model & 24,634 & 4 &, 000 \\
\hline
\end{tabular}

Tabel di atas menunjukkan nilai Chi-square sebesar 24,634 dengan nilai probabilitas (sig.) sebesar 0,000 kurang dari 0,05. Karena itu dapat disimpulkan bahwa variabel-variabel firm size, financial distress, debt level dan managerial ownership secara simultan, berpengaruh signifikan terhadap keputusan hedging perusahaan manufaktur yang terdaftar di BEI. Dengan kata lain, model logistik yang dihasilkan layak untuk dipertahankan atau diinterpretasi. 


\section{Koefisien Determinasi}

Koefisien determinasi merupakan salah satu langkah untuk menilai kelayakan model regresi logisitik. Koefisien determinasi, yang menggambarkan besarnya kemampuan variasi atau perubahan nilai variabel independen dalam menjelaskan perubahan nilai variabel respon, diindikasikan dengan nilai Cox $\&$ Snell $R$ dan Negel kerke $R$.

Tabel 4.5

Koefisien Determinasi

Model Summary

\begin{tabular}{|c|c|c|r|}
\hline Step & -2 Log likelihood & $\begin{array}{c}\text { Cox \& Snell R } \\
\text { Square }\end{array}$ & Nagelkerke R Square \\
\hline 1 & $196,948^{a}$ &, 141 &, 189 \\
\hline
\end{tabular}

Diperoleh nilai Cox $\mathcal{E}$ Snell $\mathrm{R}$ sebesar 0,141 dan Nagelekerke $R$ sebesar 0,189. Berdasarkan koefisien pertama, koefisien determinasi yang dihasilkan adalah sebesar $14,1 \%$, artinya perubahan variabel responden keputusan hedging perusahaan manufaktur mampu dijelaskan oleh perubahan variabel firm size, financial distress, debt level dan kepemilikan manajerial sebesar 14,1\%. Sedangkan berdasarkan koefisien kedua, maka besarnya koefisien determinasi adalah sebesar $18,9 \%$, artinya perubahan variabel responden keputusan hedging perusahaan manufaktur mampu dijelaskan oleh perubahan variabel firm size, financial distress, debt level dan manaerial ownership sebesar $18,9 \%$.

\section{Uji Ketepatan Prediksi}

Tabel 4.6

Classification Tablea

\section{Uji Ketepatan Prediksi}

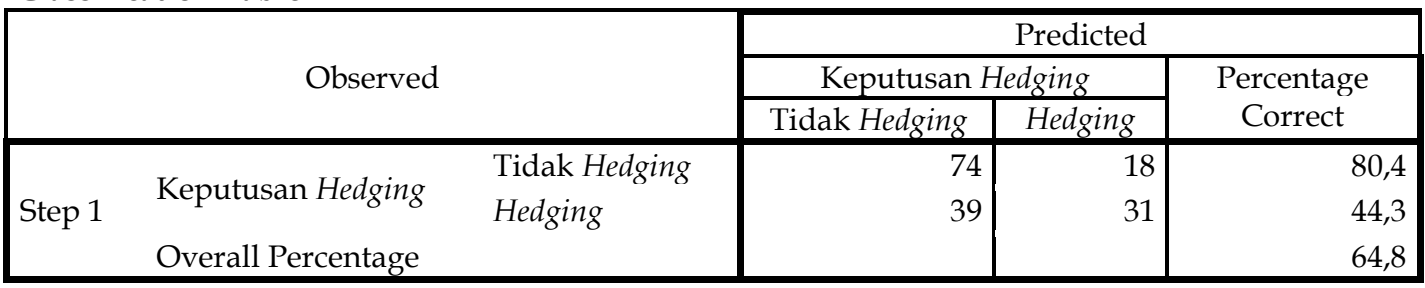

Secara keseluruhan persentase ketepatan prediksi keputusan hedging dan non hedging adalah sebesar $64,8 \%$. Sedangkan ketepatan prediksi perusahaan dengan keputusan non hedging adalah sebesar 80,4 dan perusahaan dengan keputusan hedging adalah sebesar $44,3 \%$.

\subsubsection{Model Persamaan Regresi Logistik}

Model persamaan regresi logistik merupakan persamaan prediksi probabilitas atau kemungkinan munculnya nilai 1 (hedging) dibandingkan dengan nilai 0 (non hedging) berdasarkan asumsi perubahan nilai variabel independen.

\section{Tabel 4.7}

Model Persamaan Regresi Logistik

Variables in the Equation

\begin{tabular}{|c|c|c|c|c|c|c|c|c|c|}
\hline & \multirow[t]{2}{*}{ B } & \multirow[t]{2}{*}{ S.E. } & \multirow[t]{2}{*}{ Wald } & \multirow[t]{2}{*}{ Df } & \multirow[t]{2}{*}{ Sig. } & \multirow[t]{2}{*}{$\operatorname{Exp}(B)$} & \multicolumn{2}{|c|}{ 95\% C.I.for EXP(B) } \\
\hline & & & & & & & & Lower & Upper \\
\hline \multirow{5}{*}{ Step $1^{\mathrm{a}}$} & Size & ,338 & 111 & 9,362 & 1 & ,002 & 1,402 & 1,129 & 1,742 \\
\hline & FD & ,004 & ,003 & 2,577 & 1 & 108 & 1,004 & ,999 & 1,010 \\
\hline & DL & 001 & ,001 & 657, & 1 & ,418 & 1,001 & ,998 & 1,004 \\
\hline & $\mathrm{MO}$ & 026 & 011 & 5,114 & 1 & ,024 & 1,026 & 1,003 & 1,049 \\
\hline & $\begin{array}{l}\text { Consta } \\
\text { nt }\end{array}$ & $-10,479$ & 3,211 & 10,647 & 1 & ,001 & ,000 & & \\
\hline
\end{tabular}

a. Variable(s) entered on step 1: Size, FD, DL, MO. 
Berdasarkan tabel di atas model persamaan regresi logistik yang dihasilkan adalah :

$$
\operatorname{Ln}\left(\frac{P}{1-P}\right)=-10,479+0,338 * \text { Size }+0,004 * F D+0,001 * D L+0,026 * M O
$$

Dimana $\mathrm{P}$ adalah probabilitas sebuah perusahaan mengambil keputusan hedging. Untuk memprediksi besarnya probabilitas atau kemungkinan sebuah perusahaan melakukan keputusan hedging atau tidak berdasarkan perubahan variabel-variabel independen maka dilakukan interpretasi terhadap nilai Exponen (B) atau nilai Odds Ratio.

\subsection{Hasil Pengujian Hipotesis}

Pengujian hipotesis analisis regresi logistik menggunakan uji Wald sebagai dasar pengambilan keputusan hasil uji. Variabel independen dinyatakan berpengaruh signifikan jika probabilitas (sig.) kurang 0,05 pada output Variables in Equation.

\section{H1 : Pengaruh Firm Size Terhadap Keputusan Hedging}

Hasil uji Wald yang diperoleh dari koefisien regresi 0,338 menunjukkan nilai probabilitas sebesar 0,002 kurang dari 0,05, maka keputusan yang diambil adalah bahwa H1 diterima atau terbukti. Artinya firm size berpengaruh positif dan signifikan terhadap keputusan hedging pada perusahaan manufaktur yang terdaftar di Bursa Efek Indonesia (BEI).

\section{H2 : Pengaruh Financial Distress Terhadap Keputusan Hedging}

Hasil uji Wald yang diperoleh dari koefisien regresi 0,004 menunjukkan nilai probabilitas sebesar 0,108 lebih besar daripada 0,05, maka keputusan yang diambil adalah bahwa $\mathrm{H} 2$ ditolak atau tidak terbukti. Artinya financial distress berpengaruh negatif dan tidak signifikan terhadap keputusan hedging pada perusahaan manufaktur yang terdaftar di Bursa Efek Indonesia (BEI).

\section{H3 : Pengaruh Debt Level Terhadap Keputusan Hedging}

Hasil uji Wald yang diperoleh dari koefisien regresi 0,001 menunjukkan nilai probabilitas sebesar 0,418 lebih besar daripada 0,05, maka keputusan yang diambil adalah bahwa $\mathrm{H} 3$ ditolak atau tidak terbukti. Artinya debt level berpengaruh negatif dan tidak signifikan terhadap keputusan hedging pada perusahaan manufaktur yang terdaftar di Bursa Efek Indonesia (BEI).

4. H4 : Pengaruh Managerial Ownership Terhadap Keputusan Hedging

Hasil uji Wald yang diperoleh dari koefisien regresi 0,011 menunjukkan nilai probabilitas sebesar 0,024 kurang dari 0,05, maka keputusan yang diambil adalah bahwa H4 diterima atau terbukti. Artinya kepemilikan manajerial berpengaruh positif dan signifikan terhadap keputusan hedging pada perusahaan manufaktur yang terdaftar di Bursa Efek Indonesia (BEI).

\subsection{Pembahasan}

\subsubsection{Pengaruh Firm Size terhadap Keputusan Hedging}

Hasil pengujian hipotesis pertama (H1), Dimana hasil uji Wald menunjukkan bahwa firm size berpengaruh positif dan signifikan terhadap keputusan hedging pada perusahaan manufaktur di BEI. Variabel firm size memiliki nilai odds ratio sebesar 1,402, yang berarti bahwa firm size atau total asset yang besar memiliki peluang melakukan hedging adalah 1,402 kali lebih tinggi daripada perusahaan dengan firm size yang lebih kecil.

Perusahaan yang berukuran besar memiliki aktivitas operasional yang luas dan dapat lebih beresiko. Berdasarkan teori jika ukuran perusahaan (firm size) naik, maka akan diikuti dengan peningkatan profitabilitas dan semakin besar ukuran perusahaan (firm size), semakin besar risiko yang dihadapi oleh perusahaan tersebut. Untuk mengurangi risiko 
nilai tukar yang mungkin timbul, perusahaan dapat mengatasinya dengan melakukan hedging.

Beberapa penelitian empiris mendukung hasil penelitian ini antara lain penelitian yang dilakukan oleh Judge (2005), Raghavendra dan Velmurugan (2014). Dimana hasil penelitian tersebut menjelaskan bahwa ukuran perusahaan memiliki hubungan yang positif dan signifikan terhadap keputusan hedging. Selain itu, penelitian Nguyen and Faff (2003) dan Putro (2012) mengungkap bahwa ukuran perusahaan memiliki pengaruh positif signifikan terhadap keputusan hedging.

\subsubsection{Pengaruh Financial Distress terhadap Keputusan Hedging}

Hasil pengujian hipotesis kedua (H2), Dimana hasil uji Wald menunjukkan bahwa financial distress berpengaruh negatif dan tidak signifikan terhadap keputusan hedging perusahaan manufaktur di BEI. Nilai odds ratio untuk variabel ini sangat kecil yakni 1,004, artinya perusahaan dengan financial distress yang lebih besar hanya mempunyai kemungkinan melakukan hedging sebesar 1,004 kali dibandingkan dengan perusahaan dengan financial distress kecil.

Untuk mengurangi kesulitan keuangan maka perusahaan membutuhkan biaya yang besar. Sehingga untuk mengurangi kesulitan keuangan perusahaan lebih baik melakukan keputusan hedging. Menurut Smith dan Stulz (1985), biaya kesulitan keuangan memberikan penjelasan yang mungkin mengapa perusahaan lindung nilai.

Penelitian ini didukung oleh beberapa penelitian lain, yaitu penelitian yang dilakukan oleh Nuzul dan Lautania (2015) yang mendapatkan hasil bahwa financial distress tidak berpengaruh terhadap keputusan hedging. Selain itu, penelitian Yustika (2019) juga menyimpulkan bahwa bahwa financial distress tidak berpengaruh terhadap keputusan hedging.

\subsubsection{Pengaruh Debt Level terhadap Keputusan Hedging}

Hasil pengujian hipotesis ketiga (H3), Dimana hasil uji Wald menunjukkan bahwa debt level berpengaruh negatif dan tidak signifikan terhadap keputusan hedging perusahaan manufaktur di BEI. Nilai odds ratio untuk variabel ini sangat kecil yaitu 1,001, artinya perusahaan dengan debt level yang lebih tinggi hanya mempunyai kemungkinan melakukan hedging sebesar 1,004 kali dibandingkan dengan perusahaan dengan debt level kecil.

Peusahaan memiliki sejumlah risiko yang didapat langsung akibat dari jenis usaha dari perusahaan tersebut (Risiko Bisnis). Risiko ini dapat membesar karena utang yang dimiliki terkadang tidak hanya menggunakan mata uang Indonesia, tetapi juga mata uang asing. Sehingga dapat mempengaruhi perusahaan dalam pembayaran utangnya karena ada risiko fluktuasi nilai tukar. Pengelolaan risiko fluktuasi nilai tukar ini dapat dilakukan melalui kebijakan hedging.

Hasil penelitian ini didukung oleh beberapa penelitian yang telah dilakukan oleh Estiari (2017) mengungkap bahwa leverage atau debt level berpengaruh negatif dan tidak signifikan yang terhadap keputusan hedging. Sebaliknya penelitian yang dilakukan Nguyen et al. (2003) dan Putro (2012) justru menemukan bahwa leverage atau debt level berpengaruh positif dan signifikan terhadap keputusan hedging.

\subsubsection{Pengaruh Managerial Ownership Terhadap Keputusan Hedging}

Hasil pengujian hipotesis keempat (H4), Dimana hasil uji Wald menunjukkan bahwa Managerial ownership berpengaruh positif dan signifikan terhadap keputusan hedging pada perusahaan manufaktur di BEI. Variabel kepemilikan manajerial memiliki nilai odds ratio sebesar 1,026, yang berarti bahwa perusahaan dengan rasio kepemilikan manajerial yang lebih tinggi memiliki peluang melakukan hedging adalah 1,026 kali lebih tinggi daripada perusahaan dengan rasio kepemilikan manajerial yang lebih kecil. 


\section{NATIONALLY ACCREDITED JOURNAL - DECREE NO. 21/E/KPT/2018}

Managerial ownership yang tinggi akan lebih memungkinkan untuk melakukan keputusan hedging untuk menghindari risiko. Seperti pendapat Sprcic \& Sevic (2012) yang mengatakan bahwa kepemilikan saham yang lebih besar akan lebih memilih untuk memanajemen risiko yang ada untuk mencegah dan meminimalkan kerugian. Sementara mereka dengan kepemilikan opsi yang lebih besar akan lebih memilih manajemen risiko kurang.

Penelitian yang telah dilakukan oleh Ameer (2010) mendukung hasil penelitian ini, dimana kepemilikan manajerial berpengaruh positif signifikan terhadap keputusan hedging.

\section{KESIMPULAN DAN SARAN}

\subsection{Kesimpulan}

1) Firm size berpengaruh positif dan signifikan terhadap keputusan hedging pada perusahaan manufaktur yang terdaftar di Bursa Efek Indonesia.

2) Financial distress berpengaruh negatif dan signifikan terhadap keputusan hedging pada perusahaan manufaktur yang terdaftar di Bursa Efek Indonesia.

3) Debt level berpengaruh negatif dan signifikan terhadap keputusan hedging pada perusahaan manufaktur yang terdaftar di Bursa Efek Indonesia.

4) Managerial Ownership berpengaruh positif dan signifikan terhadap keputusan hedging pada perusahaan manufaktur yang terdaftar di Bursa Efek Indonesia.

\subsection{Saran}

1. Bagi Perusahaan

Sebaiknya perusahaan mulai memikirkan untuk melakukan hedging untuk melindungi perusahaannya dari risiko perubahan nilai mata uang. Terutama bagi perusahaan yang sudah melakukan kerjasama dan perdagangan internasional.

2. Bagi Investor

Investor yang ingin melakukan investasi pada perusahaan perlu mengetahui variabel-variabel yang terkait dengan keputusan hedging, karena dengan begitu investor tahu bagaimana suatu perusahaan mampu mengatasi atau bahkan mengantisipasi risiko yang akan terjadi.

3. Bagi Peneliti Selanjutnya

- Peneliti dapat menambahkan variabel lain yang mungkin berpengaruh terhadap keputusan hedging dan diharapkan dapat melakukan penelitian pada sektor lain yang lebih banyak melakukan atau menerapkan hedging.

- Penelitian selanjutnya diharapkan dapat melibatkan scope waktu yang lebih lama, atau paling singkat periode waktu 5 tahun.

\subsection{Keterbatasan Penelitian}

1. Beberapa perusahaan manufaktur di Indonesia memiliki tingkat hutang yang sangat tinggi. Hal ini menyebabkan estimasi rata-rata DER yang bias dari rata-rata kebanyakan perusahaan yang ada.

2. Terdapat banyak perusahaan tanpa kepemilikan manajerial atau nilai kepemilikan manajerial nol selama periode waktu penelitian. 


\section{DAFTAR PUSTAKA}

Ahmad, N., \& Haris, B. (2012). Factors for using derivatives : Evidence from Malaysian Non-financial companies. Research Journal of finance and accounting, 3, 1.

Ameer, R. (2010). Determinant of Corporate Hedging in Malaysia. International Business Research, 3, p. 1.

Brigham, Eugene F.\&Joel F. Houston. (2006). Fundamental of Financial Management : Dasardasar Manajemen Keuangan. Jakarta: Salemba Empat.

Brigham, Eugene F. \& Joel F. Houston. (2010). Dasar-Dasar Manajemen Keuangan, Buku 1 edisi kesebelas. Jakarta : Salemba Empat.

Clark, Ephraim \& Judge, Amrit. (2005). “Motives for Corporate Hedging : Evidence from the UK". Working Paper, Middlesex University, London, UK.

Darwis, Herman. (2009). "Corporate Governace Terhadap Kinerja Perusahaan". (Jurnal Keuangan dan Perbankan, Vol 13, No 3 September 2009, hal. 418-430.

Estyari, Kadek Indah. (2017). Pengaruh Leverage, Profitabiltas, Ukuran Perusahaan dan Likuiditas Terhadap Keputusan Hedging Perusahaan Manufaktur yang Terdaftar pada Bursa Efek Indonesia 2013-2014. Journal of Magister Manajemen.

Fahmi, Irham. (2014). Analisis Kinerja Keungan. Bandung: Alfabeta.

Ghozali, Imam. (2016). Aplikasi Analisis Multivariete Dengan Program IBM SPSS 23 (Edisi 8). Cetakan ke VIII. Semarang : Badan Penerbit Universitas Diponegoro.

Guniarti, Fay. (2014). Faktor-faktor yang Mempengaruhi Aktivitas Hedging dengan Instrumen Derivatif Valuta Asing. Dinamika Manajemen, 5.

Harahap, Sofyan Syafri. (2007). Analisis Kritis Atas Laporan Keuangan. Edisi Pertama. Jakarta : Raja Grafindo Persada.

Hidayat, dan Meiranto, W. (2014). Prediksi Financial Distress Perusahaan Manufaktur Di Indonesia. Journal of Accounting. Vol. 3 ISSN (Online).

Imanta, Dea \& Satwiko, Rutji. (2011). Faktor-faktor yang Mempengaruhi Kepemilikian Managerial. Jurnal Bisnis. Vol 13. No 1. Hlmn 60-70.

Indri, Siti. (2012). Faktor-faktor yang mempengaruhi keputusan hedging market to book value, likuiditas, leverage, growth opportunity, financial distresspada perusahaan manufaktur yang terdaftar di Bursa Efek Indonesia.Journal

Krisdian, N. P., \& Badjra, I. B. (2017). Pengaruh Ukuran Perusahaan, Tingkat Hutang, dan Kesulitan Keuangan terhadap Keputusan Hedging pada Perusahaan Manufaktur Indonesia. 6. Journal

Levi, Maurice D. (2001). Keuangan Internasional. Yogyakarta : Andi Yogyakarta.

Madura, Jeff (2006). Keuangan Perusahaan Internasional. Buku 1 edisi kedelapan. Jakarta: Salemba Empat.

Mahfudz, \& Kussulisyanti, M. J. (2016). Analisis Faktor-faktor Mempengaruhi Keputusan Hedging dengan Derivatif Valuta Asing (Studi pada perusahaan Non-Financial Yang terdaftar di Bursa Efek Indonesia Periode 2011 - 2014. Diponegoro journal of Management, 5.

Munawir. (2004). Analisa Laporan Keuangan. Edisi Keempat, Cetakan Ketiga Belas. Yogyakarta : Liberty.

Nguyen, H and Faff. (2003).Optimal Fand Portofolio Return Optimisation in US Futures Markets,Working Paper.Queensland University of Technology.

Nuzul, H., \& Lautania, M. F. (2015). Pengaruh Leverage Finacial Distress dan Growth Option terhadap Aktivitas Hedging pada Perusahaan Non-Keuangan Yang Terdaftar di Bursa Efek Indonesia. 2. Journal 
Paranita, Ekayana. (2011). "Kebijakan Hedging dengan Derivatif Valuta Asing pada Perusahaan Publik Di Indonesia". Jurnal Seminar Ekonomi Terapan

Prasetiono, \& Hidayah, N. (2016). Faktor Penentu Perusahaan Melakukan Pengambilan Keputusan Hedging pada Derivatif Valuta Asing (Studi kasus pada Perusahaan Manufaktur yang Terdaftar di BEI periode 2011-2014). Diponegoro Journal of Management, 5.

Putri, Indah Ningrum. (2012). Pengaruh Kepemilikan Manejerial, Kepemilikan Instiusional, Dividen, Pertumbuhan Perusahaan, Free Cash Flow dan Profitabilitas Terhadap Kebijakan Hutang. Jurnal Bisnis dan Akuntansi Vol 11 No 3. Hlmn 187-270.

Putro, Septama Hardanto. (2012). Analisis Faktor yang Mempengaruhi Penggunaan Instrumen Derivatif Sebagai Pengambilan Keputusan Hedging (Studi Kasus Pada Perusahaan Automotive and Allied Products yang Terdaftar Di BEI Periode 20062010). E-Journal Business Review Diponegoro. Volume 1, Nomor 1, Tahun 2012, Halaman 1-11.

Raghavendra, R., \& Velmurugan, P.S. (2014). The Determinan of Curency Hedging In Indian IT Firms. Journal of Business and Financial Affairs, Vol.3.1-7

Seftianne, H. 2011. "Faktor-Faktor yang Mempengaruhi Struktur Modal pada Perusahaan Publik Sektor Manufaktur". Jurnal Bisnis dan Akuntansi. Vol. 13, No. 1, hal : 39-56.

Subagya, R. (2015). Analisis Laporan Keuangan. (10, Ed.)

Subramanyam, K., \& Wild, J. J. (2012). Analisis Laporan Keuangan (10 ed.). Jakarta : Salemba Empat.

Sugiyono. (2014). Metode Penelitian Pendekatan Kuantitatif Kualitatif dan R \& D. Bandung : Alfabeta.

Sunaryo, T. (2009). Manajemen Risiko Financial. Jakarta : Salemba Empat.

Thouraya, Triki. (2005). Research on Corporate Hedging Theories: A Critical Review of the Evidence to Date. Departement of Finance and Canada Research Chair Risk Management, HEC Montreal.

Utomo, Linawati. (2000). "Instrumen Derivatif : Pengenalan dalam Strategi Manajemen Resiko Perusahaan". Jurnal Akuntansi \& Keuangan. Vol. 2. No. 1, Mei, pp. 53-68.

Uyanto, S.S. (2006). Pedoman Analisis Data dengan PSS. Yogyakarta : Graha Ilmu

Widarjono, Agus. (2010). Analisis Statistika Multivariat Terapan. Edisi Pertama.Yogyakarta : STIM YKPN

Yustika Ahmad Erani. (2019). Analisis disparitas dan aliran investasi. Jurnal penelitian Unri Volume VII. 